\title{
Scrutinization of COVID-19 Pandemic in Terms of History of Medicine and Medical Ethics*
}

\section{COVID-19 Pandemisinin Tıp Tarihi ve Etiği Açısından İncelenmesi}

Kadircan Keskinbora'

iMD.,PhD., Bahcesehir University, School of Medicine, History of Medicine and Medical Ethics

https://orcid.org/0000-0003-1940-1026

\begin{abstract}
Purpose: The world has been facing an enormous global epidemic with unprecedented personal, social and economic consequences in recent years. The World Health Organization has declared this incident as a "pandemic". Main aim of the article is to discuss the effects of the pandemic in terms of Medical History and Medical Ethics are evaluated.

Methods: In order to appreciate the significance and widespread impact of pandemics, the past epidemics and outbreaks were investigated. Outbreaks recorded in history due to their impact on human history since 5th century BC till COVID pandemics which started in 2019 and continues to date have been investigated.
\end{abstract}

Results: It was established that the infections might cross the boundaries, and could destroy every rule and factor such as prestige, wealth, weapon, power and so on. For this reason, it was recodrded that special precautions should be taken and special arrangements should be made in epidemics and especially in pandemics. Based on this findings, the damages and effects of the COVID-19 pandemic on humanity were recorded in terms of both Medical History and Medical Ethics.

Discussion: In this article, after remarking on some epidemic diseases that affected the whole world and their consequences, related topics such as scientific development, epidemic management, distribution of resources, pandemic and civilization products ethics are scrutinized. The pandemic is a problem not only of a region, but of the whole world and humanity, and has been the case so throughout history. For this reason, international cooperation is indispensable in the struggle and the search for a solution.

Keywords: Pandemic, COVID-19, Ethics, History of Medicine, Allocation of limited resources.

öz

Amaç: Dünya, son yıllarda benzeri görülmemiş kişisel, sosyal ve ekonomik sonuçları olan muazzam bir küresel salgınla karşı karşıyadır. Dünya Sağlık Örgütü de, bu olayı "pandemi” olarak ilan etmiştir. Makalenin temel amacı pandeminin etkilerini Tıp Tarihi ve Tıp Etiği açısından tartışmaktır.

Yöntem: Pandemilerin önemini ve yaygın etkisini değerlendirmek için geçmiş epidemiler ve salgınlar araştırıldı. MÖ 5. yüzyıldan başlayarak 2019 yılında başlayan ve günümüze kadar devam eden COVID salgınlarına kadar insanlık tarihine etkileri nedeniyle tarihe kaydedilen salgınlar araştırıldı. Bu araştırmada etkileri açısından öne çıkan ve tarihe kaydedilen pandemiler tarihsel bir perspektiften incelendi. Her bir büyük salgının tarihsel, ekonomik ve sağlık üzerindeki etkileri incelendi.

Bulgular: Enfeksiyonların sınırları aşabileceği anlaşıldı. Prestij, servet, silah, güç vb. her türlü kuralı ve faktörü yok edebileceği tespit edildi. Bu nedenle salgın hastalıklarda ve özellikle pandemilerde özel önlemler alınması ve özel düzenlemelerin yapılması gerektiği saptandı. Bu bulgulardan hareketle COVID-19 salgınının insanlık üzerindeki zararları ve etkileri hem Tıp Tarihi hem de Tıp Etiği özellikleri ve terimleriyle kaydedildi.

Tartışma: Bu araştırmada, tüm dünyayı etkileyen bazı salgın hastalıklara ve bunların sonuçlarına değinildikten sonra bilimsel gelişim, salgın yönetimi, kaynakların dağıtımı, pandemi ve uygarlık ürünleri etkisiyle ilgili konular irdelendi. Bu konuların Tıp Tarihi ve Tıp Etiği açısından etkileri değerlendirildi. Küreselleşme ve ulaşımın yaygınlığı nedeniyle, dünyanın herhangi bir yerinde bir salgın tüm ülkeler için bir tehdit haline gelmektedir. Aslında pandemi sadece bir bölgenin değil, tüm dünyanın ve insanlığın sorunudur ve tarih boyunca böyle olmuştur. Bu nedenle mücadelede ve çözüm arayışında uluslararası işbirliği vazgeçilmezdir.

Anahtar Kelimeler: Pandemi, COVID-19, Etik, Tıp Tarihi, Sınırlı kaynakların dağıtımı.

"Lokman Hekim Dergisi, 2021; 11 (2): 340-352

DOI: $10.31020 /$ mutftd.871944

e-ISSN: 1309-8004, ISSN 1309-761X

Geliş Tarihi - Received: 31 Ocak 2021; Kabul Tarihi - Accepted: 18 Nisan 2021

Iletişim - Correspondence Author: Kadircan Keskinbora <kadircan.keskinbora@gmail.com> 


\section{Introduction}

The world has been facing an enormous global epidemic with unprecedented personal, social and economic consequences in recent years. Myriads of people in more than 173 countries and regions worldwide have been exposed to the outbreak of new coronavirus, SARS-CoV-2 and its associated disease, COVID-19. The World Health Organization has declared this incident as a "pandemic". The word pandemic is a combination of the words "pan", which means all, and "demos", which means people, and is the general name given to epidemics (epidemics) that spread and spread over a wide area, such as the surface of a continent or even the world. ${ }^{1}$

The spread of microorganisms leading to illness and pandemics instigated the panic caused by the serial deaths, and the humanity has faced and will continue facing highly devastating consequences. Because of the advances in transportation and globalization, an epidemic anywhere in the world is now a threat to all. Many serious acute illnesses evolving in a short time challenge the capacities of health systems of both developing and developed countries. No country's health system can be potent enough to deal with the problems that too many sick people will create in a short time. Therefore, the pandemic is a problem not only of a region, but of the whole world and humanity, and has been so throughout history. For this reason, international cooperation is essential in the struggle and the search for a solution.

The purpose of this article is to examine the COVID-19 outbreak in terms of History of Medicine and Medical Ethics.

\section{Methods}

Outbreaks recorded in history due to their impact on human history since 5th century BC till COVID pandemics which started in 2019 and continues to date have been investigated.

Internet search engines, novels on epidemics, articles on epidemics, regulations and orders related to epidemics of health organizations (World Health Organization, Turkish Medical Association, Public Health Association), have been reviewed with the keywords "Pandemic, Epidemic, Black Death, Right to Health".

After touching upon the outbreaks in history due to their effects, areas such as scientific development, epidemic management, distribution of resources, ethics of pandemic and civilization products have been evaluated from the perspectives of their historical effects, History of Medicine, and Medical Ethics.

Considering the breadth of the topics, although a full discussion of each may require a very long time, the discussion have been confined to summarizing the most prominent issues and especially on COVID-19.

\section{Examples of Important Epidemics Which Affected History}

I will present chronologically the outstanding features of the epidemics that changed history and their historical effects:

Athens Plague: In $430 \mathrm{BC}$ (and then $406 \mathrm{BC}$ ), the people of Athens were hit by a deadly disease during the Peloponnesian war (431-404 BC) against their great rival Sparta. The historian Thukydides survived the disease of this unknown killer and vividly explained his symptoms: "People had severe fever and pain that started suddenly in their heads, redness in their eyes and inflammation, bleeding inside the throat and tongue. They emitted an unnatural, smelly breath. But this was just the beginning; sneezing, coughing, diarrhea, vomiting, and severe spasms began to follow. Live skin was covered with pustules and ulcers, a burning and irreversible thirst was added to this table." 
The outbreak caused the death of Pericles, the leader of Athens, and almost a third of the people over the next four years. At the end of the plague, Athens lost $1 / 3$ of its army. The Attic Delos Union broke up, the superiority of Athens collapsed, the powerhouse began to slide towards Rome. ${ }^{3}$

The Carthage Army captured the city of Syracuse in 397 BC. While this siege was going on well, a plague epidemic broke out again in the Carthage army at the beginning of 396 BC. Carthage lost so much that it not only stopped the siege to Syracuse, but also Carthage military power in Sicily collapsed. Carthage lost almost all of the Greek cities in Sicily, which it had previously captured. In Sicily, only Western Sicily, which had been in the hands of Carthaginians, remained attached, and only the Elymians remained as Carthage allies. In this war, the two parties fighting because of the outbreak could not even conclude a peace or armistice treaty that would clearly show that peace was achieved. ${ }^{4}$

Antoninus Plague: Known as the Galen plague, it was an epidemic disease brought by the Roman soldiers who returned to the Empire from expeditions in the Near East. Academics suspected it to be smallpox or measles, but the true cause remains uncertain. The epidemic caused the Roman emperor Lucius Verus ( $d$. 169 AD) to die. Verus was the regent of Marcus Aurelius Antoninus. ${ }^{5}$ This death caused Antoninus, his family names, to become associated with the outbreak. The epidemic reappeared 9 years later, according to a Roman historian Dio Cassius (155-235), and it 2000 people a day in Rome. This number was a quarter of those affected by the epidemic, and thus this disease was given a $25 \%$ mortality rate. In some areas it annihilated a third of the population and devastated the Roman army, severely affecting the Epidemic Roman culture and literature and the Indo-Roman trade relations in the Indian Ocean. ${ }^{6}$

\section{The Historical Impact of the Antoninus Plague}

The historical effects of the Antoninus plague and the other strikes known as the St. Cypriot Plague Epidemic in Carthage in the Roman colony in North Africa emerged as important turning points: The chaos era after the Antoninus Plague provided the opportunity to spread Christianity, which was subjected to heavy torture by pagan Roman rulers. This epidemic lasted more than twenty years. The newborn Christian church benefited from the chaos caused by the Cypriot (St Cyprian) Plague. Christians, who won the hearts of people with their care of patients and their support in the funerals, spread their religion to the whole imperial geography with the belief in the hereafter and heaven that they inspired by the pagan society that was writhing in despair. ${ }^{7}$

After the Iznik (Nikea) Council gathered in 325, Christianity became the official state religion of the Roman Empire. Bypassing the patronage of Christianity, the Byzantine Emperor undertook a new political mission. With the addition of a new masterpiece like Hagia Sophia in 537, new ones were added to the charm of the city of Constantinople. Already, in the city, which is one of the most beautiful cities in the world, the places of art and entertainment in the Theater Street were busy all day and night. The city started to live 24 hours. Justinian annexed Western Rome and started making plans to convert the Roman Empire into a single empire. However, in 541, with the outbreak of the plague epidemic in the city, all life was turned upside down. Population declines also damaged the army, the economic and administrative structure of the empire. Farmer deaths led the peasant population to migrate to the cities. The fields were abandoned, agricultural production collapsed. ${ }^{8}$

Justinian Plague: The Justinian Plague Outbreak lasted more than two years. The plague, which probably killed half of the European population, made it easier for Muslims to seize the Byzantine provinces in the Near East and Africa in later years. ${ }^{9}$

The Justinian Outbreak has definitely eliminated efforts to unify the Western and Eastern Roman Empires. This time, the plague that shook the Byzantine first made the rivals of the Sassanids and allowed for the 
spread of Islam towards the north and east thus causing the world power balance to change and pushing the Persians out of the historical scene. It paved the way for a new actor, the Muslims, to enter the world stage. $^{6}$

Black Death (Great Plague): The plague which is frequently encountered in Europe and is an extremely dangerous and infectious disease brought an unprecedented disaster to Europe in its terrible attack in the 14th century. The plague started in China and spread all over the world. ${ }^{10}$ According to the writer Henry Kington, the plague first appeared in India and first reached Asia Minor and then to Sicily in October 1347. The arrival of the plague in Europe was the handiwork of Asian merchants selling plagued furs that they bought from China. It is stated by the researchers that fleas and mice living on the ships were also instrumental in the spread of this disease. ${ }^{11}$ Apart from that, at that time, the Head of the Crimean Tatars, Canibek, surrounded the Genoese port and threw his own plague into the city with catapults and infected the Italians with the disease. Genoa, Messina and Venice were the first cities to accommodate Italians with the plague. Afterwards, the Plague epidemic came to Paris in 1348, and in 1349, it reached again to the homeland of the Tatars from where it originated after Scotland and Scandinavia. ${ }^{11}$

Although Christians endured this epidemic, which they had desperately labeled as "a wrath of God," they found the cure in taking refuge in a number of idols, saints, and a number of things remaining from the saints. They used to move the leftovers from them in cities, believing that they would cure the epidemic. Thus, the clergy took over the medicine business. They also tried to treat the epidemic with crosses, candles, rites of exorcism. By announcing "Not once but many times religious ceremonies must be held and repented before God." they organized mass repentance rituals, filling all the healthy and sick people into churches and cathedrals, aggravating the existing conditions. One of the most common ways to calm God's anger was to kill Jews who were thought to have caused the epidemic. Societies were frightened because the outbreak could not be prevented. To escape, they ran away from the outbreak, causing it to spread more. In this sense, "burning the plagued people", "witch" and "Jewish hunt" were famous delineations in the Western societies in the dark of the Middle Ages. Minorities, different people (foreigners, witches) were accused, tormented, and killed. ${ }^{11,12}$

Physician Simon de Covino stated that: "all the crime was at the great conjunction between Jupiter, Saturn and Mars at noon on March 20,1345, at 14 degrees below the bucket sign, and said that the most enemy celestial bodies, especially Saturn, are infinitely negative effect and therefore first of all, the day comes to the angel of death...."13

The most accurate and effective method among the measures during this period was the quarantine implementation. The word "quarantine" comes from Italian: It is the process of ships arriving from infected ports anchoring for 40 days (quaranta giorni) before landing in Venice and accepting the vessel into the port, unless there was a disease on board. In 1374, it was reported that all ships and passengers should be deployed on the island of San Lazzaro near the city (another word - Lazaretto-waiting area), until the private health council in Venice allowed them to enter the city. The declaration is accepted as the first official quarantine regulation in Europe. The Republic of Ragusa enforced the quarantine of all ships and commercial caravans from infected areas for the pandemic in 1377 and enacted a groundbreaking law (Terentino law): the 30-day isolation requirement was extended to 40 days. ${ }^{14}$

\section{Changes after the Great Plague Outbreak}

This outbreak also disrupted social, moral, cultural and religious values. The authority of the church was shaken, the way of questioning religious beliefs was opened. Clergymen were also looking for ways to eradicate the plague. When the authority of the church weakened, a new sect, Protestantism, was born. 
While the plague reveals the fact that medicine science is still very young, it laid the foundations of the concept of public health. In some cities, plague houses were established, quarantine implementation was initiated and detailed death records were kept. ${ }^{12}$

Changes were made in the field of architecture and urbanization. From the houses with straw ceilings, where black rats (and fleas) swarmed, the construction of brick houses with tiled roofs started. The deaths depleted the workforce and reduced the amount of arable land, bringing the end of the current feudal system. While this collapse in the medieval economic system had political consequences on the one hand, it also triggered the conception of new economic views and models in Europe on the other. ${ }^{13,14}$

By fostering individual freedoms, it introduced the new European human model, while nurturing its strong nation-state ideal. Due to the rivalry arising between nation-states, states needed to cultivate strong armies and navies. ${ }^{15}$

\section{Impacts after Outbreak of COVID-19}

Some issues that are influenced by all of us, that stand out and whose importance is better perceived lately are presented:

The human beings accepted their incapability and weakness against microbes and epidemics. In general, it was acknowledged that the world was not prepared for a pandemic or major epidemic. Public Health measures regained their importance. The importance of the contribution of individuals arose in terms of measures and practices.

Outbreaks proved to be fatal to man and destructive to the economy. It was witnessed many times that the world must cooperate with science.

The epidemic showed the virtue of respect for life-related elements.

It was once again understood that governments played a critical central role in maintaining human health and safety at times of crisis. The debate on the concept of the Social State begun.

It can be predicted that the form of communication will become more virtual. In this case, we may encounter the problem of people not socializing face-to-face in the future.

It can also be predicted that the world will face dramatic changes in the way it consumes energy. Could this have any benefit in preventing the global climate disaster?

Policy makers accepted that the warnings of the experts needed to be heeded more. They also became more inclined to concede that the worst could strike without any warning.

\section{The Behavior of Microorganisms}

The genetic change potential of microorganisms makes it possible for new microbial factors to emerge. These developments are also important for medical professionals and public health professionals, because they are the group that will carry the most responsibility and deal with the problems caused by epidemics and their victims. Therefore, medical organizations and all those dealing with health need to lead the education and information of society and decision-makers on the effects and the prevention of these epidemic diseases. ${ }^{16}$

World health services have suffered difficulties in dealing with problems caused by AIDS and antibiotics resistant microorganisms, wars, refugees and the crowd of unhealthy conditions and the growing needs of the aging population. Managing the problems of too many sick people in a short time will overwhelm the capacity of these health systems drastically. ${ }^{16}$ 


\section{Researching the Source of the Problem}

International action must be taken to eliminate the harmful consequences of potentially serious epidemics, regardless of their origins. International cooperation is important for establishing a universal common view in epidemics. Cooperation programs are needed in all countries to respond to epidemic diseases and provide early diagnosis and identification, to develop surveillance programs, to educate community leaders, community and subject specialists in health education and information, to conduct research on disease prevention, early diagnosis and treatment. ${ }^{16,17}$ Filiation and surveillance are the two key activities that may facilitate such endeavors:

Filiation: It is a method of screening the people who are in contact with the person (s) infected with the disease agent in order to determine the source of the disease. In other words, "field inspection" is the study on determining the source of the radiation and the effect and / or taking protection and control measures including the contacts. ${ }^{17}$

Surveillance: It is the work that will be performed for the source of the disease and the contacts, the detection of the cases, the control of the contacts, the record keeping process that will enable data analysis. It is important to establish a reliable and qualified active surveillance system to keep the epidemic process under control. ${ }^{17}$

\section{Outbreak Management}

We are living in a period when ordinary health measures are not enough to guarantee public health. The outbreak process differs from those of other diseases, especially in terms of risks. With the application of the screening test, the active case detection studies, the definitive diagnosis and treatment of suspicious cases, the investigation of contacts, the isolation / quarantine application process are additional fundamental topics. The public health approach implements its own methods of combatting, guided by the science of epidemiology. In such cases where liberty is restricted, every effort should be made to preserve the "Protection of the Right to Privacy" meticulously. It is very important for the authorities to inform the public transparently, accurately and timely. Public resources are to be used for medical, economic and social needs. ${ }^{17}$

\section{Prominent Issues in the Outbreaks}

Economical Particularities: In the "Epidemic" incident involving many fields and scientific disciplines, there are especially economic losses which cannot be foreseen. The workplaces that need to be closed due to quarantine measures and many similar economic measures can cause great losses for both the employer and the worker. Potentially material losses can be compensated by the principles of social state. It is the duty of the state to prevent approaches such as stockpiling, black market, etc. aimed at benefiting from the epidemic. ${ }^{17}$

Social Particularities: Social solidarity practices should be socially activated. Particular attention should be given to those people such as elderly, disabled, refugees and similar disadvantaged community groups who live in public places. ${ }^{17}$

Responsibilities of Directors of Health Institutions: Besides the policies designated by Central Health Authority at macro level, the authorities in charge of health institutions must be ready also at local scale (supplying materials if needed, establishing loop of supplying materials, revising sterilization units, assigning staff, duty system, preparing resting place for staff, transportation etc.) and should formulate suitable plans in due time..$^{17,18}$ 


\section{Supporting and Securing Healthcare Professionals}

An effective fight against the epidemic is heavily dependent on the dedicated contributions of healthcare professionals. Health professionals take vital personal risks in this process. In the case of an epidemic, healthcare professionals face the risk of death, disability, and illness in the same way as soldiers who are besieged in the front line in the event of war. In the event of death and illness, their social and financial rights should be upheld like those of the military. Therefore, it is the duty of directors to provide and circulate protective equipment, sterile materials. ${ }^{18}$

Some of the health professionals may be among the most disadvantaged members of the society (elderly, comorbid etc.). They may have less control over some duties they are expected perform. These kinds of professionals should be cared more due to their being under high risk. ${ }^{18}$

Private protective kit (PPK), one of the most crucial titles in presentation of health services should be supplied to health professionals in sufficient quantities, regularly, properly and continuously. Lacking such materials is not acceptable. Failing to provide these materials expose the health professionals to fatal risks. Shortage of sources should not constitute an excuse for lack of protective kits. ${ }^{18}$

\section{Limits of Responsibilities in Rendering Services}

The entire cohort of health professionals is subject to the risk of contracting disease in case of outbreaks. Therefore, the State has a positive duty to protect health professionals and their relatives who are under the risk of contracting the disease from the infected health professionals. When executing this duty, the State should regulate working conditions so as not to coerce the physician to choose between his life and lives of others and also to regulate and to secure health and safety of working professionals, and to provide sufficient quantity of means and instruments including PPK for health and safety of health professionals in charge in health institutions. ${ }^{18}$

The health professionals have ethical responsibilities of demanding protective and preventive measures, and activating measures amenable to them as well as notifying and keeping away from duties until recovery in case of being infected so that they would not infect other people. ${ }^{18}$

Pressures on Health Professionals: Some political pressures on health professionals may occur in case of outbreaks.

Chaotic environments exacerbated by outbreaks may trigger terror on health professionals. One of the main conditions of health authorities is to inform the public fast and correctly, to provide course of information transparently, and to avert confrontations between the patients and health professionals.

During an outbreak, the health professionals also endure anxieties and fears. Extension of processes, increase of risks, colleagues being sick or dead may cause intensification of anxieties and fears, and also cause tiredness and extinction. It is utmost important for health authorities to manage the process in such chaotic periods, and clearly designate duty descriptions, and generate algorithms for sustaining health services.

\section{International Solidarity and Cooperation}

It is the duty of the entire state to realize the "Health Right" in case the outbreak turns out to spread extensively and becomes an international problem. It is the duty and ethical responsibility of governments generates necessary systems so as to cover prevention and interference of the outbreak. This responsibility should be endorsed because it is obliged to cover not only the national but also the international society. . 16,18 
For the ethical responsibility to be based on transparency, and for the international precautions to be imported, notifications are required to take effect immediately and honestly. It is imperative to provide fast international information for stopping the outbreak and obtain health and living right. All participating people and units should collaborate by sharing the correct data on time. Indeed, U.N. The Committee on Economic, Social and Cultural Rights reveals the importance and seriousness of the issue in the statement that "given that some diseases can easily cross the borders of a State, the international community has a collective responsibility to address this problem".1,16,18

\section{Principles of Medicine Ethics in Pandemic}

Three basic principles that are generally accepted constitute the basis of pandemic ethics discussions; It subsumes the principles of being useful, respecting the autonomy of the individual and being just. In case of a pandemic, the goal of delivering healthcare services will be to provide the largest number of patients with the greatest benefit / benefits to be expected.

The principle of respect for the autonomy of the individual is important in that the healthcare employee should respect the privacy of his patient, should not practice without informing, should act honestly, and should not carry out the diagnosis and treatment, without the clarified consent of the patient.

The principle of medical confidentiality, which forms the basis of one of the oldest and most sensitive moral obligations of medicine, creates an ethical necessity for the physician to respect the secrets of his/her patient - in the sense of information that the patient does not want to be disclosed to someone else without the permission of the patient. Today, the right to protection of private life, privacy or subjectivity during medical practices takes its source from the constitutions. The "privacy" of the personal information of people benefiting from medical services should be protected.

In the Justice Principle, Fair treatment does not only require similar treatment, it also requires a different treatment, if necessary, within the specific needs of certain individuals.

The "principle of justice" in the field of health envisage individuals to benefit from social and medical opportunities fairly.

The problem in practice is how to allocate limited resources in health care services, whether there are appropriate and precise criteria for honest sharing. For example, the fair and honest distribution of medical tools and facilities to the whole community can be achieved by acting in accordance with the requirements of such criteria. ${ }^{19}$

\section{Distribution of Sources}

Planning and implementing fair distribution of health services and resources is the state's obligation. In the outbreak, the provision of additional health services required by the society should be taken into consideration without ignoring current health problems. It is essential to ensure that these services are qualified and equally accessible.

In extraordinary situations such as disasters and epidemics, limitations related to already scarce resources such as medicine, intensive care beds are among the most important problems.

\section{Triage Protocols}

Triage is a system of determining the priority of medical intervention in the battlefields and emergency departments. Pandemic is also a war-like situation. These priorities are determined according to factors such as the patient's chance of survival, the urgency of condition. Triage urgently regulates as per changing conditions in the states. From the perspective of public interest, triage aims to maximize the survival of the 
society. Triage imposes medical, moral, conscientious and ethical responsibility. When it is needed to implement triage, then necessary measures should be taken to protect patients' rights to life and treatment. Responsibility for triage should not be left to the physician who takes care of the patient. A "National Triage Ethics Committee" should be established with the participation of relevant parties in order to define and justify triage principles and establish protocols. ${ }^{18,20}$

Resources in medicine are always limited. When it comes to using limited resources, guiding principles and arguments are utilized. The primary ethical principles regarding this are the principle of justice and the principle of usefulness. The principle of triage, which is basically deciding which patient will be treated first, evolved in the battlefields. This principle requires physicians to divide the people to be treated into three groups:

1. Those who can recover even if they are not treated,

2. Those who will die even if they are treated,

3. People whose treatment will make a difference between life-death (or disability and normality).

According to this classification, the first and second groups are reserved for intervention if time remains, and priority is given to the third group. This principle seems appropriate because it puts the most in need at the top of the list (assuming we distribute healthcare according to needs) and allows for the most efficient use of limited resources. ${ }^{20}$

\section{Counter-views to Triage Principle}

It is difficult to estimate for how long this period to be limited, however ignoring the treatment would cause a serious problem, it is thought to be proper to use the narrow definition "will die soon" and in a sense we all will die soon.

Although it is fair to apply triage in emergencies or in the allocation of a very special and limited resource, it may be considered that it is unfair to apply it "to all without exception". Suppose a doctor treats a skin condition that is uncomfortable but not dangerous. Meanwhile, it is reported that there is an accident victim outside who is dying from excessive blood loss. The physician tells his patient to wait and starts dealing with the emergency. For the physician, it is correct and fair to refuse to treat the skin condition, as there are more urgent cases that must be intervened.

It is not just and fair for the public health system to reject all non-urgent cases due to urgent cases. It is one thing to give priority to the most urgent cases and entirely another thing to concentrate only on them. Though triage is only an emergency policy, it does not seem to be a fair principle on which to design entire a healthcare system or on which physicians are admonished as to how to allocate their time. ${ }^{21}$

\section{Incidents are "sudden", Intervention should be "fast"}

Medical resources that can respond to normal situations are insufficient in such situations: The number of people affected is quite high, it implies more efficient use of resources are required in order to save a large number of lives. Risks created by outbreaks cause undesirable effects on health. The events are monitored by the media. In this case, physicians are faced with exceptional situations where "intense" emotions are experienced in which individual ethical approaches must be blended in some way with the ethical requirements demanded by the society. The formerly defined ethical rules should be complementary to the individually low level ethical approaches of physicians. When the conditions are abnormal, not only ethical issues but also technical and managerial issues in providing medical services are in question. For this 
reason, ethical attitudes should be suggested in disasters in order to determine the role of the physician in the event of an outbreak.

\section{Ethical Dilemmas}

According to utilitarian (consequentialist) criteria, a "fair approach" is a requirement for all groups of assistance, so everyone should have as fair a chance as possible to access the service. Conflicts arising from the physician's decision-making position will often occur, and the ethical analysis of the decision justification - will have to be delivered at least against the conscience of the physician.

Taking into account the limitations created by the situation, the physician should make efforts to apply priorities for treatment that will save the most seriously injured people who have a chance to recover and should limit the disease to the least level of harm. He/She should be particularly sensitive to children, women and the elderly. It seems like a good way to be objective in the distribution of resources, not to leave these decisions to the choice of political leaders, community leaders or patients and their relatives and keep the aspect of public health. ${ }^{22}$

\section{Evolution - Natural Selection - Free Competition - Survival}

Along with adoption of innovation in science, we can also see The Darwinist view of evolution which represents a critical step in our way of thinking in the theory of natural selection and struggle to survive in the free competition of the capitalist era. Here, the science obtained by all the social and intellectual knowledge of ancient times and tested many times by scientific experiments, is used to approve social practice. ${ }^{23}$

\section{Research Ethics}

In this regard, it is important not to leave the principles of scientific knowledge production, even though it is an urgent need today. It is incompatible with the universal researcher's role to ignore the scientific method under the disguise of urgency, to tend to areas which exclude objectivity that is incompatible with reality, to ignore the rights of the participants, to collect data without care. The researches designed by researchers in order to benefit for the sake of their competition, publication pressure or merely their own academic future are not acceptable; benefit should be produced in line with scientific ethics and for the whole society. ${ }^{18,24}$

\section{Discussion}

In 2500 years of health history, we have seen the epidemics that shook humanity the most and the effects they caused. We observed social, administrative and health management issues and ethical dilemmas related to the recent pandemic COVID-19. Now let's discuss this latest pandemic in depth, its effects in terms of History of Medicine and Medical Ethics.

We all have heard of fear scenarios in Chinese city of Wuhan. The rapidly spreading and fatal disease images in the Lombardy region in northern Italy remain fresh in our memories. Was this the beginning of something that the first patients, intensive care professionals and nurses were not trained for? Was it an enormous public health emergency of unprecedented and uncontrollable dimensions?

\section{Pulmonology and Intensive Care Units. Are we in need of other specialties and Public Health issues?}

Although pulmonologists and intensive care physicians were trained to look after individuals with a wide range of life-threatening conditions, they never encountered a public health emergency, such as the ongoing global COVID-19 outbreak. These are professionals trained to care for patients who plan to be hospitalized in advance, with the majority of them needing intensive care after a surgery or a serious 
illness. They are not trained to deal with a catastrophe that the whole society suffered, and in many and very severe situations, with patients suddenly appearing at a hospital and demanding treatment with scarce resources. The ethical standards of patient-centered intensive care differ significantly from the ethical standards of public health. When faced with patients in need of more care than beds and ventilators available in the intensive care unit, people cannot be sure that they can maintain moral equality and a good ethical standard. This uncertainty about how to allocate limited resources fairly can also create serious ethical dilemmas and tension for clinicians.

During a pandemic, clinician physicians, nurses, responsible officers and employees of intensive care units have to face occupational hazards in their works. This is not just the risk of getting infected. Physicians and healthcare professionals also face emotional exhaustion and ethical crises.

Each patient may experience an ethical dilemma when he/she becomes aware of the tension between personal care task and the task of promoting personal equality, personal health, versus the health of their loved ones. Triage problems, namely to whom to allocate such scarce intensive care beds and other materials, mechanical ventilator, are not just for severely ill COVID-19 patients who need intensive care. In the normal course of life, the triage also concerns other critically ill patients, such as traffic accidents, occupational accidents, heart attacks, major oncological surgeries, and organ transplant surgeries.

It is necessary to look at the effects of civilization products and dizzying scientific developments on humanity from another perspective:

The Industrial Revolution is of British origin, as is known; the island of Britain was once a factory of the world. The 1930s was also a time when the myth that science was always in the interest of humanity was destroyed and was replaced by a disappointment. This was the period after the Sharing War in the West and the great crisis of 1929. Humanity realized that science and its technological outputs could have devastating consequences in society than ever before. ${ }^{25}$ World War II and the destructiveness of the atomic bomb symbolized engineers' gifts that are used extremely blindly. Now, we all know very well that sophisticated and advanced disciplines such as artificial intelligence, robotics, and genetic science can also be abused. The troubles we are witnessing today are likely to turn into a tragedy in the future. ${ }^{26}$

A power-based hierarchy has also been established in international and intranational relations. Generations that have grown in this hierarchy are shaped according to its format in their socialization processes. This social hierarchy criterion, which dominates the whole world, does not question the quality and reason of power. For power, every means from media campaigns to unethical behavior, surrounding boundaries, and negotiations of diplomatic alliances to monopolize the sectors, especially the arms industry, and outwitting of the competitors are utilized. Those who relish power put powerlessness against or opposite power to justify power. However, power must be questioned. Conscience should be emphasized. There is conscience and compassion defying power, not weakness. Because power enslaves its owner, he/she may sacrifice everything in order not to lose it. The greatest freedom is to abolish power. It directs its conscience to the people's own human characteristics to be "human". Mercy naturalizes man and makes him feel that he is a part of the universe he lives in..$^{27,28}$

As with pandemic, it is natural for some confrontations and conflicts to arise when it comes to crossing borders, because values valid in developed countries and values that are widely accepted in developing countries can sometimes be diametrically opposite. Recently, some have been disturbed by the development of bioethics among cultures, warning that developed countries will create a new kind of cultural imperialism on developing countries through their expertise and vast resources, which is an important problem. Others think that the counter option will consist of inefficient ethical relativism. But 
everyone seems to agree that globalization, which connects countries in many ways, has its own local characteristics when it comes to health issues. ${ }^{19}$

Healthcare, which has only one dimension in society, is accepted as a cosmopolitan, global initiative, which not only fostered but also embraced by developing countries. The Public Health Act, which emphasized the importance of environmental health and public health as a whole, started with the efforts of Edwin Chadwick in 1848. ${ }^{29}$ Thus, preventive medicine, environmental awareness and Public Health Science have served humanity as a developed and established branch of science for 150 years.

\section{Conclusion}

Outbreaks are very exasperating public health risks. For this reason, we have to develop large-scale measures, create impact assessments, document statistical information and utilize similar public health methods, especially in the guidance of subject matter experts, until the necessary relief is achieved. The pandemic process begins to occupy the agenda as a primary infection disease. However, it is a major threat with medical, psychosocial, international political, social, diplomatic and economic aspects covering many branches of medicine. Multidisciplinary approaches are required in the search for a solution, taking into account the historical memory and a multi-faceted perspective.

\section{Acknowledgement}

The author declare that he has no conflict of interest. This study was not funded. This article does not contain any studies with human participants or animals performed by the author.

\section{References}

1. World Health Organization. Health topics. [cited September 18, 2020] Available from: https://www.who.int/health-

topics/coronavirus\#tab=tab_1

2. Thukydides. Peloponnesos Savaşı. İstanbul: Hürriyet Yay., 1976, s.116-7.

3. Clifford HE, Evjen HD. The Plague at Athens: A new oar in muddied waters. Journal of the History of Medicine and Allied Sciences 1962;17:258-263. doi:10.1017/s1047759400016524

4. The Antonine Plague. [cited October 20, 2020]. Available from: https://classicalwisdom.com/culture/history/the-antonineplague/

5. Bowsky, William MB. The Impact of the Black Death upon Sienese Government and Society. Speculum 1964;39:1-34.

6. Duncan-Jones RP. The Impact of the Antonine Plague. Journal of Roman Archaeology 1996;9:108-136.

7. Horgan J. Plague of Cyprian, 250-270 CE. [cited December 22, 2020]. Available from: https://www.ancient.eu/article/992/plagueof-cyprian-250-270-ce/

8. Üç İmparatorluğa Başkentlik Yapan Şehir: İstanbul. [cited January 6, 2021]. Available from: http://www.istanbul.gov.tr/ucimparatorluga-baskenlik-yapan-sehir-istanbul

9. Kaya A. Doğudaki Roma'nın Bizanslaştığı Devir: I. Justinianus Dönemi. CÜ Sosyal Bilimler Dergisi, 2013;37:17-40.

10. Bennett JM, Hollister CW. Medieval Europe: A Short History. New York: McGraw-Hill, 2006, p. 326.

11. Keskinbora KH. Bilmekle Bilmemek Arasındaki Sınır. Herkese Bilim ve Teknoloji Dergisi 31.10.2016 [cited December 25, 2020]. Available from: http://www.herkesebilimteknoloji.com/haberler/yasam/bilmekle-bilmemek-arasindaki-sinir

12. D. Herlihy, The Black Death and the Transformation of the West. Cambridge, Massachusetts: Harvard University Press, 1997, p. 29.

13. Geoffrey P. Europe in crisis, 1598-1648. Wiley-Blackwell. 2001, p.7. [cited December 25, 2020].

Available from: http://books.google.com/books?id=qy8y8rHgucoC\&pg=PA7\&dq\&hl=en\#v=onepag\&q=\&f=false

14. Griggs MB. The Black Death Actually Improved Public Health. Available from: www.smithsonianmag.com/author/mary-bethgriggs/ retrieved: December 26, 2020

15. Maddicott, J. R. 1997. Plague in Seventh-Century England. Past and Present 1997;156:7-54.

16. World Health Organization. Ethical considerations in developing a public health response to pandemic influenza, World Health Organization 2007, EPR publications. [cited December 2, 2020]. Available from: www.who.int/csr/resources/publications/

17. Keskinbora KH. Salgınların Öğrettiklerinden Biri: Sorunun Kaynağını Denetlemek. TIDE Academia Research 2020;2:9-32.

18. Salgınlara Yönelik Türk Tabipleri Birliği Etik Kurulu Görüşü. [cited January 20, 2021]. Available from:

https://www.ttb.org.tr/makale_goster.php?Guid=4da9a49c-7674-11ea-b329-aa051764b049\# 
19. Büken NÖ. Pandemik influenza ve etik. Hacettepe Tıp Dergisi 2010;41:62-68.

20. Oktay C. Afetlerde Hastane Öncesi Müdahale ve Triaj. [cited May 22, 2020]. Available from: https://www.ttb.org.tr/STED/sted0402/afet.pdf

21. Öner-Şimşek D. Triaj Sistemlerine Genel Bakiş Ve Türkiye'de Acil Servis Başvurularini Etkileyen Faktörlerin Lojistik Regresyon ile Belirlenmesi. Sosyal Güvence Dergisi 2018;7:84-115. DOI: 10.21441/sguz.2018.66

22. Kaçar F. Afetlerde Etik Değerler. [cited August 6, 2020]. Available from:

http://auzefkitap.istanbul.edu.tr/kitap/acildurumveafetyonetimi_ue/afetlerdeetikdegerler.pdf

23. Bernal JD. Bilimin Toplumsal İşlevi. Çev: Ok T., İstanbul: Evrensel Basım, 2011, 2011, ss. 24-25.

24. Pandemi Döneminde Bilimsel Araştırma Etiği. [cited October 10, 2020]. Available from: https://korona.hasuder.org.tr/pandemidoneminde-bilimsel-arastirma-etigi/

25. Çankaya H. Biyoteknoloji ve İnsan Hakları. Ankara Üniversitesi Sosyal Bilimler Ensititüsü Kamu Hukuku (Genel Kamu Hukuku) Anabilim Dalı. Doktora Tezi. Ankara, 2009. [cited December 9, 2020]. Available from:

https://dspace.ankara.edu.tr/xmlui/bitstream/handle/20.500.12575/37408/250273.pdf?sequence=1\&isAllowed=y

26. Keskinbora KH. Medical ethics considerations on artificial intelligence. J Clin Neuroscience 2019;64:277-282. DOI:

10.1016/j.jocn.2019.03.001

27. Covid-19-Hub, Tüm Dünyayı Korona Pandemisine Karşı Bilinçlendiriyor. [cited June 22, 2020]. Available from:

https://www.yee.org.tr/tr/haber/covid-19-hub-tum-dunyayi-korona-pandemisine-karsi-bilinclendiriyor

28. Keskinbora KH, Jameel M. Ethical Aspects of Interventional Neuroscience: Nanoneuronal Interfaces (April 2019). In: eLS. John

Wiley \& Sons, Ltd: Chichester. DOI: 10.1002/9780470015902.a0028647

29. Mondadori A. Tıp Tarihi (The Hamlyn History of Medicine). İstanbul: Hürriyet Gaz. Mat., 1998, s.156-7. 